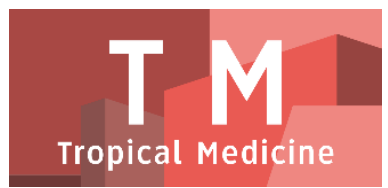

PAPER - OPEN ACCESS

\title{
Pengujian Kandungan Total Fenol Ekstrak Etanol Tempuyung (Shoncus arvensis L.)
}

\author{
Author : Annisa Mulia Hapsari \\ DOI $\quad: 10.32734 /$ tm.v1i1.75 \\ Paper Page : $284-290$
}

Volume 1 Issue 1 - 2018 TALENTA Conference Series: Tropical Medicine (TM)

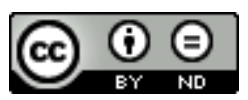

This work is licensed under a Creative Commons Attribution-NoDerivatives 4.0 International License.

Published under licence by TALENTA Publisher, Universitas Sumatera Utara
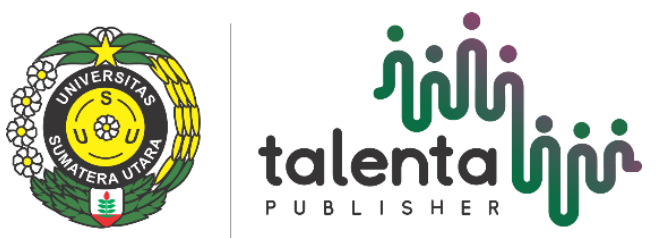


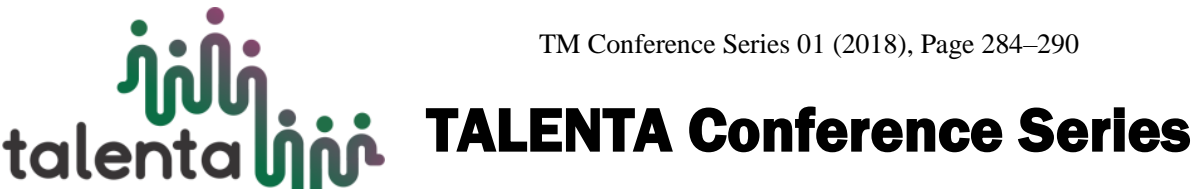

Available online at https://talentaconfseries.usu.ac.id

\section{Pengujian Kandungan Total Fenol Ekstrak Etanol Tempuyung (Shoncus arvensis L.)}

\author{
Annisa Mulia Hapsari ${ }^{a}$, Dr. Masfria M. S., Apt. ${ }^{\text {, }, ~ A m i n a h ~ D a l i m u n t h e ~ S . S i ., ~ M . S i ., A p t ~}$ \\ ${ }^{a}$ Fakultas Farmasi, Universitas Sumatera Utara 20155, Indonesia
}

annisamoi13@gmail.com

\begin{abstract}
Abstrak
Daun tempuyung merupakan salah satu tumbuhan obat tradisional Indonesia yang banyak dimanfaatkan untuk pengobatan batu ginjal, anti inflamasi, disentri, radang dan rematik. Tempuyung banyak mengandung senyawa flavonoid yang merupakan golongan fenol terbesar. Penelitian ini dimulai dengan pengumpulan dan persiapan sampel, skrining fitokimia, pembuatan ekstrak etanol, dan pengujian kandungan total fenol dengan metode kolorimetri pereaksi Folin-Ciocalteu menggunakan spektrofotometer UV-Vis dengan asam galat sebagai baku pembanding. Hasil skrining fitokimia menunjukkan daun tempuyung mengandung senyawa flavonoid. Penetapan kadar total fenol menggunakan metode spektrofotometri pereaksi FolinCiocalteu didapat nilai regresi $\mathrm{y}=0,00077 \mathrm{x}+0,03667$ dengan nilai $\mathrm{r}^{2}=0,99757$ sehingga didapat nilai rata - rata kadar total fenol $45,04 \pm 0,46 \mathrm{mg}$

GAE/g ekstrak..
\end{abstract}

Kata Kunci: Template, USU seminar, Tempuyung, Total fenol;

\section{Pendahuluan}

Daun tempuyung di Indonesia digunakan sebagai obat untuk menghancurkan batu ginjal. Selain itu juga digunakan sebagai obat mengobati memar akibat terbentur dengan cara menempelkannya pada bagian yang bengkak, infeksi usus, disentri, wasir, antiradang, menghilangkan rasa lesu, pegal-pegal dan rematik (Wahyudi, 1986).

Tempuyung banyak mengandung senyawa kimia, seperti golongan flavonoid (kaemferol, luteolin-7-O- glukosida dan apigenin-7-O-glukosida), kumarin, dan taraksasterol (Sriningsih dkk., 2012). Daun tempuyung mengandung senyawa kimia antara lain lutein, flavon, flavonol dan auron. Di dalam tumbuhan, flavonoid ada dalam bentuk glikosida dan aglikon flavonoid (Pramono dkk., 1993). Dan pada ekstrak etanol diketahui banyak mengandung senyawa metabolit sekunder alkaloid dan flavonoid (Wadekar, J., Sawant, R., dkk., 2012).

Senyawa dengan aktivitas antioksidan yang diteliti adalah senyawa fenolat. Senyawa fenolat dalam tumbuhan dapat berupa fenol, antraquinon, asam fenolat, kumarin, flavonoid, lignin dan tanin (Harborne, 1987).

Senyawa fenolat telah diketahui memiliki berbagai efek biologis seperti aktivitas antioksidan melalui mekanisme sebagai pereduksi, penangkap radikal bebas, pengkhelat logam, peredam terbentuknya oksigen singlet serta pendonor elektron. Kadar total senyawa fenolat dapat ditentukan secara spektrofotometri dengan menggunakan metode Folin-Ciocalteu dan sebagai pembanding digunakan asam galat. Kandungan fenolat total dalam tumbuhan dinyatakan dalam GAE (gallic acid equivalent) yaitu jumlah kesetaraan miligram asam galat dalam 1 gram sampel (Gheldof \& Engeseth, 2002). 


\section{Metode Penelitian}

\subsection{Bahan}

Bahan-bahan yang digunakan dalam penelitian ini meliputi daun tempuyung (Shoncus arvensis L.),kertas saring dan akuades. Bahan-bahan kimia lainnya yang berkualitas pro analisis adalah Folin- Ciocalteu, metanol, toluen, kloroform, kloralhidrat, kalium iodida, bismuth(III) nitrat, besi(III) kloarida, asam klorida pekat, asam sulfat pekat, timbal(II) asetat, natrium karbonat, dan asam galat. Bahan kimia berkualitas teknis; etanol 96\%.

\subsection{Alat}

Alat-alat yang digunakan dalam penelitian ini meliputi alat-alat gelas laboratorium, blender, lemari pengering, rotary evaporator, seperangkat alat destilasi penetapan kadar air, tanur, neraca analitik, mikroskop, object glass, labu alas bulat, tabung reaksi, corong, kertas saring, plat tetes, pipet tetes, corong pisah, penjepit tabung, spatula, cawan penguap, kertas perkamen, alumunium foil, beaker glass, kurs porselen dan spektrofotometer UV-Visibel.

\subsection{Penyiapan Sampel}

Sampel penelitian berupa daun tempuyung yang berasal dari Desa Besukun Kecamatan Sibolangit Kabupaten Deli Serdang, Sumatera Utara. Daun selanjutnya dibersihkan, dikeringkan dan dihaluskan sehingga diperoleh serbuk simplisia.

\subsection{Pembuatan Ekstrak Etanol}

Serbuk simplisia kemudian dimaserasi dengan pelarut etanol $96 \%$ selama 7 hari dengan diaduk sesekali. Kemudian maserat dikumpulkan dan di pekatkan dengan menggunaakan rotary evaporator sehingga diperoleh ekstrak etanol kental.

\subsection{Skrining Fitokimia}

Simplisia dan ekstrak etanol selanjutnya di uji skrining fitokimia untuk mengetahui golongan senyawa yangterkandung dalam daun tempuyung. Pengujian ini meliputi pengujian alkaloid, flavonoid, glikosida, tanin, saponin dan steroid/triterpenoid.

\subsection{Penetapan Kandungan Total Fenol}

Penetapan kandungan total fenol ekstrak daun tempuyung dilakukan secara spektrofotometri menggunakan reagen Folin-Ciocalteu dan asam galat sebagai pembanding. Prinsip dari metode ini yaitu terbentuknya senyawa kompleks berwarna biru akibat reaksi antara senyawa fenolik pada sampel dengan reagen Folin-Ciocalteu dalam suasana basa yang dapat diukur dengan spektrofotometer visibel, lalu disetarakan dengan asam galat (Orak, dkk., 2006). 


\subsubsection{Pembuatan larutan induk baku Asam Galat}

Dibuat larutan asam galat dengan konsentrasi $500 \mathrm{ppm}$. Sebanyak 5,0 mg asam galat dilarutkan dalam $10 \mathrm{ml}$ metanol pro analysis.

\subsubsection{Penentuan operating time}

Dibuat larutan asam galat dengan konsentrasi $500 \mathrm{ppm}$. Kemudian diambil larutan sebanyak $0,1 \mathrm{ml}$ dan dimasukkan kedalam tabung reaksi. Ditambahkan 7,9 ml akuades dan 0,5 ml larutan Folin-Ciocalteu. Kemudian divortex selama selama satu menit. Larutan di pindahkan kedalam labu tentukur $10 \mathrm{ml}$ kemudian di cukupkan dengan larutan Natrium Karbonat $20 \%$. Diukur absorbansi larutan pada panjang gelombang $765 \mathrm{~nm}$ setiap 1 menit dan diamati kapan larutan tersebut mulai menghasilkan absorban yang stabil yang akan digunakan sebagai operating time.

\subsubsection{Penentuan panjang gelombang maksimum Asam Galat}

Dibuat larutan asam galat dengan konsentrasi $500 \mathrm{ppm}$. Kemudian diambil larutan sebanyak 0,1 ml dan dimasukkan kedalam tabung reaksi. Ditambahkan 7,9 ml akuades dan 0,5 ml larutan Folin-Ciocalteu.

Kemudian divortex selama selama satu menit. Larutan di pindahkan kedalam labu tentukur $10 \mathrm{ml}$ kemudian di cukupkan dengan larutan Natrium Karbonat $20 \%$. Kemudian larutan diinkubasi selama waktu operating time. Ukur panjang gelombang maksimum menggunakan spektrofotometer visibel pada rentang $400 \mathrm{~nm}-800 \mathrm{~nm}$.

\subsubsection{Pembuatan kurva kalibrasi Asam Galat}

Dibuat larutan asam galat dengan konsentrasi 15,$625 ; 31,25 ; 62,5 ; 125 ; 250$ dan 500 ppm. Kemudian diambil masing-masing larutan sebanyak 0,1 ml dan dimasukkan kedalam tabung reaksi. Ditambahkan 7,9 ml akuades dan 0,5 ml larutan Folin-Ciocalteu. Kemudian divortex selama selama satu menit. Larutan dipindahkan ke dalam labu tentukur $10 \mathrm{ml}$ kemudian dicukupkan dengan larutan Natrium Karbonat $20 \%$. Kemudian larutan diinkubasi selama waktu operating time. Diukur absorbansinya pada panjang gelombang maksimum dan didapat kurva kalibrasi asam galat serta persamaan garis linear $\mathrm{y}=\mathrm{ax}+\mathrm{b}$.

\subsubsection{Penetapan kandungan Total Fenol}

Sebanyak 10,0 mg sampel ekstrak etanol daun tempuyung dilarutkan dalam $10 \mathrm{ml}$ methanol. Diambil larutan sebanyak 0,1 ml dan dimasukkan ke dalam tabung reaksi. Ditambahkan 7,9 ml akuades dan 0,5 ml larutan FolinCiocalteu. Kemudian divortex selama selama satu menit. Larutan dipindahkan ke dalam labu tentukur $10 \mathrm{ml}$ kemudian dicukupkan dengan larutan Natrium Karbonat $20 \%$. Kemudian larutan diinkubasi selama waktu operating time. Ukur absorbansinya menggunakan spektrofotometer visibel pada panjang gelombang maksimum sebanyak 5 kali untuk satu kali pengukuran dan diambil rata -ratanya. Pengukuran dilakukan dengan pengulangan sebanyak 3 kali

Kadar total fenol ekstrak daun tempuyung dihitung dengan menggunakan substitusi nilai-nilai absorbansi rata-rata sampel ke dalam persamaan regresi linear yang didapat dari kurva kalibrasi untuk mendapatkan konsentrasinya. Nilai konsentrasi sampel yang didapat kemudian disusbtitusikan lagi kedalam rumus perhitungan kadar total fenol berikut :

$$
\text { Kadar total fenol }=\frac{x \cdot V \cdot F P}{B S}
$$




\begin{tabular}{|c|c|c|}
\hline \multirow[t]{4}{*}{ Keterangan } & $: x$ & = Konsentrasi (ppm) \\
\hline & $\mathrm{V}$ & $=$ Volume larutan sampel (ekstrak) (ml) \\
\hline & FP & $=$ Faktor pengenceran larutan sampel \\
\hline & BS & $=$ Berat sampel $(\mathrm{g})$ \\
\hline
\end{tabular}

Kadar total fenol disajikan dalam satuan mg ekuivalen asam galat / gram sampel (mg GAE/g).

\section{Hasil dan Pembahasan}

\subsection{Skrining Fitokimia}

Hasil skrining fitokimia terhadap simplisia dan ekstrak etanol daun tempuyung diketahui bahwa mengandung golongan senyawa - senyawa kimia seperti pada Tabel 1.

Tabel 1 Hasil pemeriksaan skrining fitokimia simplisia dan ekstrak daun tempuyung

\begin{tabular}{lccc}
\hline \multirow{2}{*}{ No. } & Pemeriksaan & \multicolumn{2}{c}{ Hasil } \\
\cline { 3 - 4 } & & Serbuk Simplisia & Ekstrak Etanol \\
\hline 1 & Alkaloid & + & + \\
2 & Flavonoid & + & + \\
4 & Glikosida & + & + \\
5 & Saponin & + & + \\
6 & Tanin & + & + \\
\hline
\end{tabular}

Keterangan : (+) (mengandung senyawa)

(-) (tidak mengandung senyawa)

\subsection{Penetapan Kandungan Total Fenol}

Penetapan kadar fenol total dilakukan dengan cara metode spektrofotometri menggunakan pereaksi FolinCiocalteu. Prinsip dari metode ini adalah terbentuknya senyawa kompleks berwarna biru akibat reaksi antara senyawa fenolik dengan Folin-Ciocalteu yang dapat diukur pada panjang gelombang $775 \mathrm{~nm}$. Pereaksi ini mengoksidasi fenolik-hidroksi mereduksi asam heteropoli (fosfomolibdat-fosfotungstat) yang terdapat dalam pereaksi folin ciocalteu menjadi suatu kompleks molibdenum- tungsten berwarna biru yang dapat dideteksi dengan spektrofotometer. Semakin besar konsistensi senyawa fenolik maka semakin banyak ion fenolat yang dapat mereduksi heteropoli (fosfomolibdat-fosfotungstat) menjadi kompleks molibdenum-tungsten sehingga warna biru yang dihasilkan semakin pekat. Senyawa fenolik bereaksi dengan reagen Folin-Ciocelatu hanya dalam suasana basa agar terjadi disosiasi proton pada senyawa fenolik menjadi ion fenolat. Suasana basa ini dibentuk dengan menambahkan Na2CO3 20\% (Alfian dan Susanti, 2012).

Senyawa fenol yang digunakan sebagai pembanding adalah asam galat. Pemilihan asam galat didasarkan atas ketersediaan substansi yang stabil dan murni (Rahmawati, 2009).

\subsubsection{Hasil penentuan operating time}

Penetapan kadar fenol dimulai dengan melakukan operating time larutan baku asam galat dengan konsentrasi 500 ppm segera setelah penambahan reagen Folin-Ciocalteu dan larutan Na2CO3 20\% pada panjang gelombang $765 \mathrm{~nm}$. 
Larutan tersebut mulai menghasilkan nilai absorban yang stabil pada menit ke 90. Dengan demikian dipilih waktu pendiaman selama 90 menit sejak percampuran sampel.

\subsubsection{Hasil penentuan panjang gelombang serapan maksimum}

Pengukuran panjang gelombang maksimum menggunakan larutan baku asam galat dengan konsentrasi 500 ppm, dilakukan pengukuran pada menit ke-90 setelah penambahan reagen Folin-Ciocalteu dan proses pengocokan selama 1 menit serta dibasakan dengan $\mathrm{NaCO} 320 \%$ menghasilkan panjang gelombang maksimum $775 \mathrm{~nm}$.

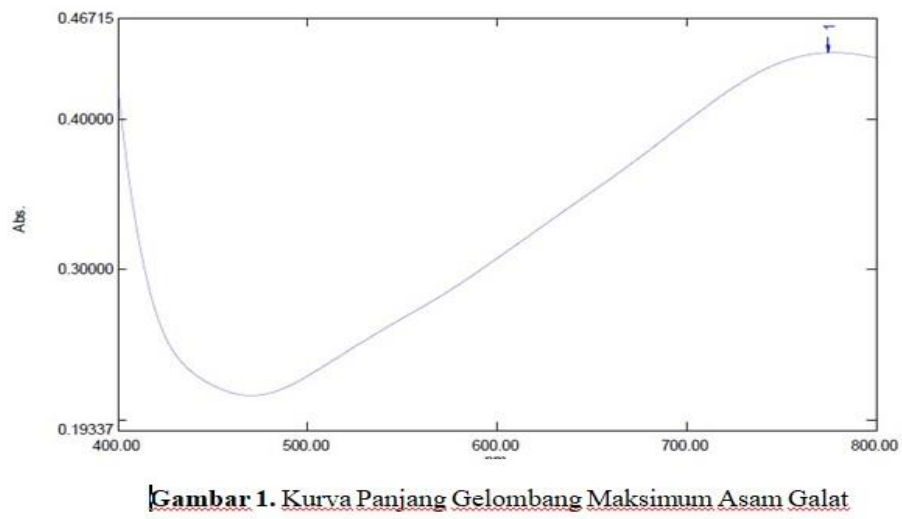

\subsubsection{Hasil penentuaan kurva kalibrasi asam galat}

Kurva kalibrasi dibuat dengan mengukur absorbansi larutan dengan konsentrasi 15,625; 31,25; 62,5; 125; 250 dan 500 ppm pada panjang gelombang $775 \mathrm{~nm}$.

Tabel 2. Aborbansi Standart Asam Galat

\begin{tabular}{cc}
\hline Konsentrasi $(\mathrm{ppm})$ & Absorbansi \\
\hline 15,625 & 0,04813 \\
31,25 & 0,05702 \\
62,5 & 0,09088 \\
125 & 0,13991 \\
250 & 0,21802 \\
500 & 0,42700 \\
\hline
\end{tabular}

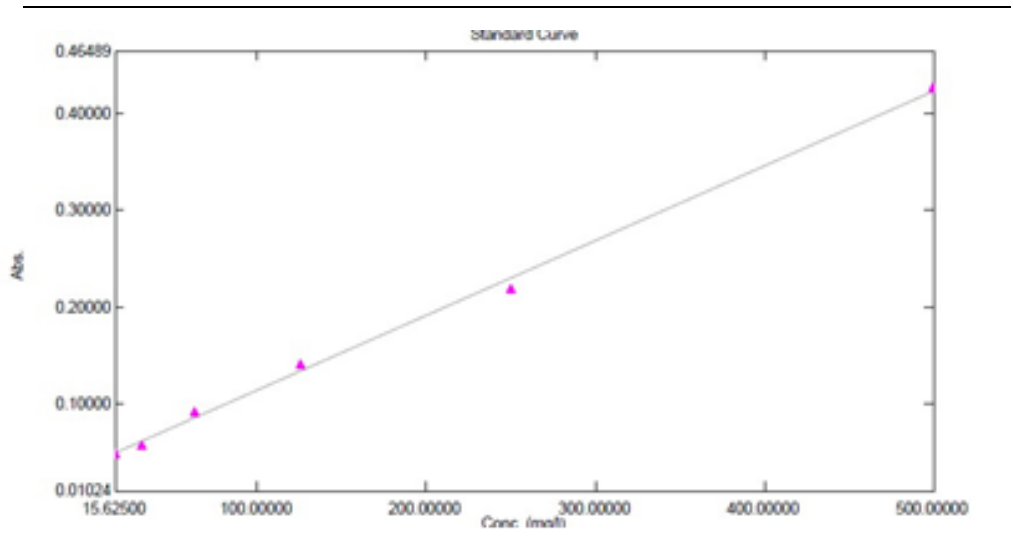


Gambar 2. Kurva kalibrasi standart asam galat

Kurva kalibrasi didapat dari hubungan berbagai kadar asam galat dengan absorbansi yang terbentuk. Dari kurva kalibrasi ini diperoleh nilai $\mathrm{r}^{2}$. Nilai $\mathrm{r}^{2}$ berkisaran antara 0 sampai 1 yang menunjukkan seberapa dekat nilai perkiraan untuk analisis regresi yang mewakili data yang sebenarnya. Dari kurva kalibrasi diatas diperoleh persamaan garis regresi $\mathrm{y}=0,00077 \mathrm{x}+0,03667$ dengan nilai $\mathrm{r}^{2}=0,99757$.

\subsubsection{Hasil pengukuran kadar total fenol}

Kadar total fenol dihitung dengan mensubstitusikan nilai absorban (y) sampel larutan ekstrak etanol daun tempuyung pada panjang gelombang maksimum ke dalam persamaan regresi linear $\mathrm{y}=\mathrm{ax}+\mathrm{b}$ yang diperoleh dari kurva kalibrasi asam galat sehingga diperoleh konsentrasinya (x). Nilai $\mathrm{x}$ kemudian disubstitusikan dalam rumus perhitungan kadar total fenol. Pengukuran kadar total fenol dilakukan dengan pengulangan sebanyak 5 kali dan diambil rata - ratanya.

Tabel 3. Rata-rata kandungan total fenol

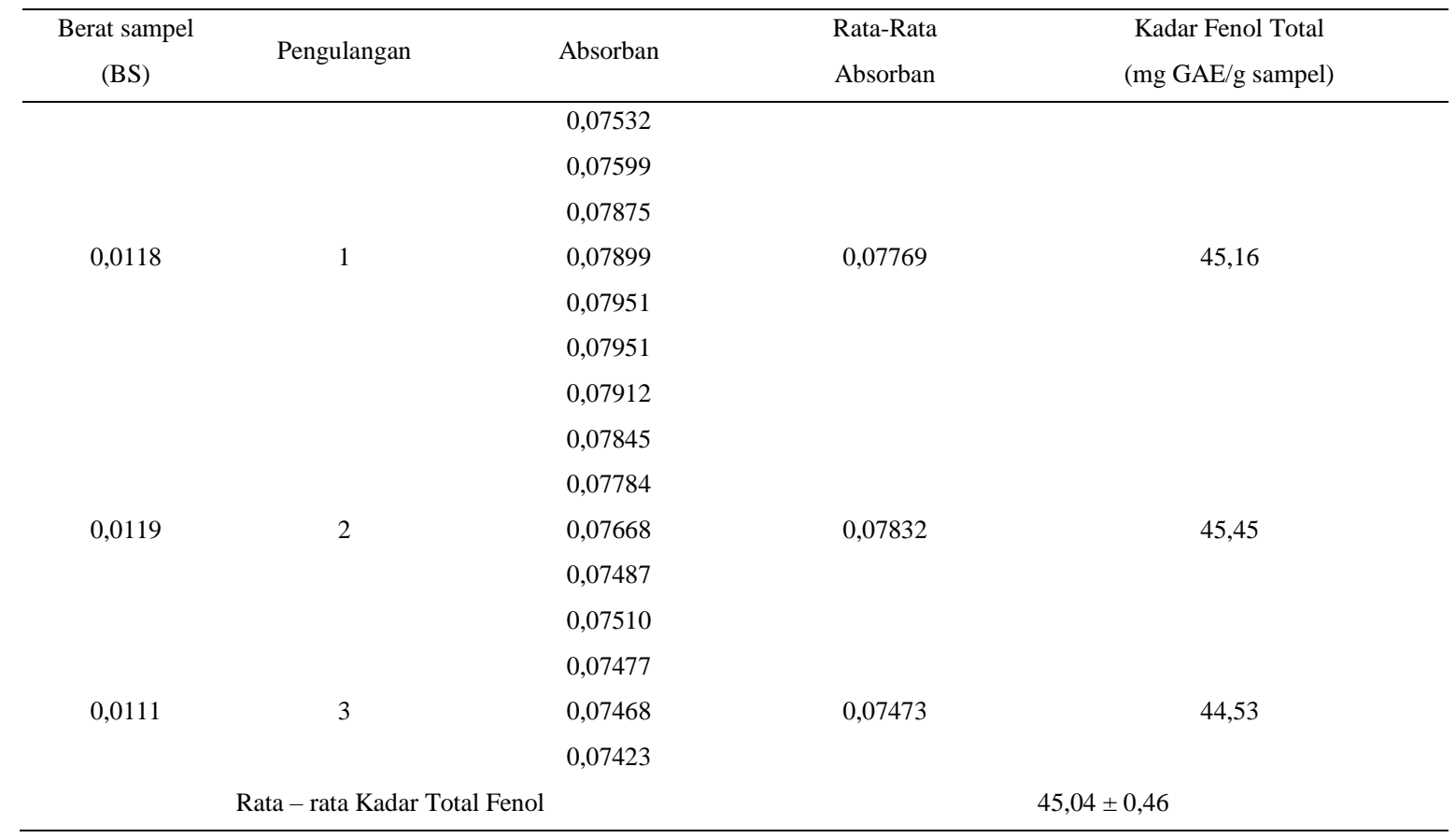

Dari tabel diatas, dapat disimpulkan bahwa kadar total fenol yang terdapat dalam ekstrak etanol daun tempuyung sebesar 45,04 \pm 0,46 $\mathrm{mg} \mathrm{GAE} / \mathrm{g}$ ekstrak.

Kadar total fenol dipengaruhi oleh jenis pelarut. Fenol merupakan senyawa yang bersifat polar sehingga kelarutannya paling tinggi dalam pelarut polar. Pelarut yang bersifat polar mampu melarutkan fenol lebih baik sehingga kadarnya dalam ekstrak menjadi tinggi (Moein dan Mahmood,2010).

\section{Daftar Pustaka}

[1] Alfian, R., dan Susanti, H. (2012). Penetapan Kadar Fenolik Total Ekstrak Metanol Kelopak Bunga Rosella Merah (Hibiscus sabdariffa Linn) dengan Variasi Tempat Tumbuh secara Spektrofotometri. Jurnal Ilmiah Kefarmasian. 2(1): 73-80Harborne, 
J.B. (1987). Metode Fitokimia Penuntun Cara Modern Menganalisa Tumbuhan. Penerjemah: Kosasih Padmawinata dan Iwang Soediro. Terbitan Kedua. Bandung: Penerbit ITB. Halaman 47-102 \& 152-153.

[2] Gheldof, N \& Engeseth, NJ., 2002, Antioxidant capacity of honeys from various floral sources based on determination of oxygen radical absorbance capacity and inhibition of in vitro lipoprotein oxidant in human serum samples, Journal of Agricultural and Food Chemistry, 50 (10): 3050-3055

[3] Harborne, J.B. (1987). Metode Fitokimia Penuntun Cara Modern Menganalisa Tumbuhan. Penerjemah: Kosasih Padmawinata dan Iwang Soediro. Terbitan Kedua. Bandung: Penerbit ITB. Halaman 47-102 \& 152-153.

[4] Moein, S. dan Mahmood, R.M. (2010). Relationship Between Antioxidant Properties and Phenolics in Zhumeria Majdae. Journal of Medicinal Plants Research. 7: 517-521.

[5] Orak, H.H. (2006). Total Antioxidant Activities, Phenolics, Anthocyanins, Polyphenoloxidase Activities In Red Grape Varieties. Journal of Polish Agricultural University Food Science and Technology 9(118).

[6] Pramono S., Sumarsono, Wahyono S. (1993). Flavonoid Daun Shoncus arvensis L. Senyawa Aktif Pembentuk Kompleks dengan Batu Ginjal Berkalsium. Jakarta : Warta Tumbuhan Obat Indonesia. Vol 2. Halaman 5-7.

[7] Rahmawati dan Anita. (2009). Kandungan Fenol Total Ekstrak Buah Mengkudu (Morinda citrifolia). Jakarta: Fakultas Kedokteran Universitas Indonesia.

[8] Sriningsih, Adji H.W., Sumaryono W., Wibowo, A.E., Chaidir, Firdayani, Kusumaningrum, S., Kartakusuma, P., (2012). Analisa Senyawa Golongan Flavonoid Herba Tempuyung (Shoncus arvensis L.)

[9] Wadekar, J., Sawant R., Naik, R., dan Bankar, A., (2012). Anthelmintic and Antibacterial Potencial of Shoncus arvensis Leaves, Padhmashri Dr. Vithalrao Vikhe Patil.

[10] Wahyudi, B., (1986). Efek menghambat pembentukan batu kandung kemih buatan dari infus tempuyung (Shoncus arvensis L.) pada tikus putih, Medika 12(10) 